\title{
"Prognosticating job satisfaction and morale determinants of public Technical Vocational Education and Training (TVET) educators"
}

\begin{tabular}{ll} 
AUTHORS & $\begin{array}{l}\text { Andrew Jeremiah } \\
\text { Abraham (Braam) Rust (D http://orcid.org/0000-0001-7263-3163 } \\
\text { Jeffrey Martin }\end{array}$ \\
\hline Andrew Jeremiah, Abraham (Braam) Rust and Jeffrey Martin (2019). \\
Prognosticating job satisfaction and morale determinants of public Technical \\
Vocational Education and Training (TVET) educators. Problems and \\
Perspectives in Management, 17(3), 350-361. doi:10.21511/ppm.17(3).2019.28
\end{tabular}

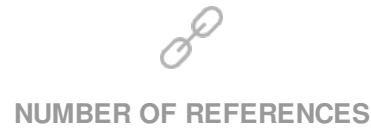

48
NUMBER OF FIGURES

1
NUMBER OF TABLES

6

(C) The author(s) 2021. This publication is an open access article. 


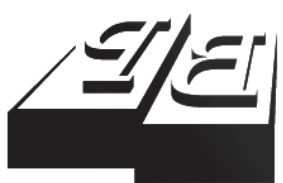

BUSINESS PERSPECTIVES

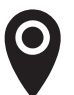

LLC "CPC "Business Perspectives" Hryhorii Skovoroda lane, 10, Sumy, 40022, Ukraine

www.businessperspectives.org

Received on: $22^{\text {nd }}$ of June, 2018 Accepted on: 27 th of February, 2019

(C) Andrew Jeremiah, Braam Rust, Jeffrey Martin, 2019

Andrew Jeremiah, Ph.D., Senior Lecturer of Human Resource Management, Namibia University of Science and Technology (NUST), Windhoek, Namibia.

Braam Rust, Ph.D., Associate Professor, Senior Lecturer, Cape Peninsula University of Technology (CPUT), Cape Town, South Africa.

Jeffrey Martin, Ph.D., Institution Management and Governance Manager, Western Cape Provincial Government, Cape Town, South Africa.

\section{(ㄷ)(i)}

This is an Open Access article, distributed under the terms of the Creative Commons Attribution 4.0 International license, which permits unrestricted re-use, distribution, and reproduction in any medium, provided the original work is properly cited.
Andrew Jeremiah (Namibia), Braam Rust (South Africa),

Jeffrey Martin (South Africa)

PROGNOSTICATING JOB SATISFACTION AND MORALE DETERMINANTS OF PUBLIC TECHNICAL VOCATIONAL EDUCATION AND TRAINING (TVET) EDUCATORS

\begin{abstract}
Rewards are a function of job satisfaction and morale. As a result, it is generally accepted that dissatisfaction with intrinsic and extrinsic rewards offered by the employer results in employee reduced job satisfaction and morale. This paper endeavors to contribute to an understanding of the effect of extrinsic and intrinsic rewards on the job satisfaction and resultant morale of employees in an organization. The paper focuses on a case study organization that adds value in the South African context. The paper reviews theoretical and empirical rewards literature and their relationship with the job satisfaction and morale of employees $(n=265)$. A quantitative research design approach which is rarely used in this type of research was adopted. A self-administered Job Descriptive Index (JDI) was utilized in collecting data. The JDI measures people's satisfaction with five (5) different aspects of the job, which are detailed in this paper. Data were processed using Software Package for Social Sciences (SPSS) version 23. The study revealed that both extrinsic and intrinsic rewards significantly influenced the job satisfaction and morale of public TVET educators in Western Cape public TVET institutions. Besides extrinsic rewards such as pay and bonuses, intrinsic rewards such as the job itself, supervision, career progression opportunities and relationships among principals and staff, and among educators and learners were found to be also instrumental in enhancing the job satisfaction and morale of educators.
\end{abstract}

Keywords

JEL Classification educators, extrinsic, intrinsic, job satisfaction, morale, rewards

J24, J28

\section{INTRODUCTION}

The debate on intrinsic and extrinsic rewards is perennial. The debate is emotional and often unresolved, since educators in general, including public TVET educators in the Western Cape, are dissatisfied with intrinsic and extrinsic rewards the Department of Higher Education and Training (DHET) offers. As a result, reduced job satisfaction and morale among public TVET educators in the Western Cape have contributed to educator absenteeism and turnover. This has negatively influenced the efficiency and performativity of public TVET institutions, hence, the need to get deeper insight into the problem (Buthelezi, 2018).

Remuneration relates to all extrinsic and intrinsic rewards such as financial returns, tangible services and benefits received by employees. Intrinsic rewards are self-administered and associated with the job itself in the sense of one achieving personal goals, having autonomy and deriving pleasure of enjoying job opportunities. Extrinsic rewards, on the other hand, include all the rewards an employee enjoys from 
sources other than the job itself such as direct compensation, indirect compensation and non-financial rewards (Meyer \& Kruger-Pretorius, 2017).

It is worth noting that rewards have always triggered heated debates between the employer and the employee. Thus, public TVET educators have always been alleged to being disposed to being dissatisfied with rewards offered by their employer. This has resulted in their reduced job satisfaction and morale (Meyer \& Kruger-Pretorius, 2017, pp. 196-197; Buthelezi, 2018; Davids, 2010).

This paper seeks to investigate the influence of rewards offered by the DHET to public TVET educators' job satisfaction and resultant morale. In studies carried out before, public TVET educators were alleged to be dissatisfied with extrinsic and intrinsic rewards offered by the DHET. However, there is a need to investigate to what extent dissatisfaction with extrinsic and intrinsic rewards contributes to the reduced job satisfaction and morale of public TVET educators, which may result in increased absenteeism and job turnover, which in turn negatively impact public TVET institutions efficiency (Buthelezi, 2018; Davids, 2010, pp. 8-9).

The paper begins with a discussion of factors that influence public TVET educators' job satisfaction and morale. This is followed by factors influencing public TVET educators' morale. Thereafter, the focus is on methodology, which is followed by a discussion of results. Finally, a relevant and appropriate conclusion is provided.

\section{FACTORS INFLUENCING PUBLIC TVET EDUCATORS' JOB SATISFACTION AND MORALE}

Public TVET educators in the Western Cape have been experiencing dissatisfaction with extrinsic and intrinsic rewards offered by the DHET and this has resulted in reduced or low job satisfaction and morale of educators since 2002. One in every four educators in general have had a sense of job dissatisfaction towards the teaching profession. In addition, $33.7 \%$ of educators in general had lack of care, interest and concern about teaching. Educators in general did not also show the zeal and interest that teaching was a profession that they always desired to belong. Furthermore, a further $38.2 \%$ of the educators in general, including public TVET educators, had negative morale about teaching. Educators felt they were not getting job satisfaction from the teaching profession (Davids, 2010; Nel et al., 2008).

It is alleged that whenever employers and employees face each other in reward negotiations, both have hidden agendas. This is the case because during reward negotiations employers and employees often endeavor to maximize personal gains. Employers adopt such attitudes, because no organization is prepared to pay employees more than is affordable. On the other hand, employees try to seize any opportunity that maximizes their gains in wage negotiations to improve their welfare. However, factors beyond employers' and employees' control also end up influencing reward negotiations and agreements. Recessions and high inflation rates are some of the unforeseen factors that can influence rewards negotiations. In South Africa, beginning in 2012, the world recession influenced reward negotiations and settlements to a large extent (Davids, 2010; Foot \& Hook, 1999, p. 259).

For most public TVET educators, money as a reward is very important, because it supplies and fulfils basic needs such as food and shelter among many other needs. This means money has the effect of enhancing the job satisfaction and resultant morale of employees. However, it can be argued that people seek more than money in their work. Although people may need money to meet their basic needs, they may also be interested in jobs that give them autonomy to engage in other pursuits like leisure and job where they are involved in the planning process, for example (Papier, 2008, p. 6; FETI, 2009).

Contributing to the dissatisfaction of public TVET educators with rewards is the fact that public TVET 
institutions in South Africa were also affected by a plethora of several policy changes from 1994. A Government White Paper of 1998 explained why it was necessary to transform public TVET institutions, to meet wide ranging needs of South Africans in search of jobs. Change started with the rationalization and merging of 152 technical colleges into 50 TVET institutions in year 2000. The institutions were expected to meet wide-ranging needs of South Africans seeking employment opportunities after having failed or dropped out of Grade 12. As a result, South Africa adopted a model used to transform Vocational Education and Training (VET) institutions in England in the 1990s. However, the several changes effected brought a lot of uncertainty, reduced job satisfaction and morale among public TVET educators and educators in general (McBride, Papier, \& Needham, 2009, p. 22; Wedekind, 2010, p. 16).

In addition, public TVET educators were expected to supervise and teach learners for at least 1,800 hours per year. Educators in general, including public TVET educators worked longer hours amounting to a 7-hour day cumulatively amounting to at least 257 days per year. This was tantamount to public TVET educators working for the whole year without taking a rest. Besides the above challenges, educators were expected to perform multiple duties in addition to extra-curricular activities and preparing lessons and marking tests and examinations at home. As a result, educators had no time to study further to improve their competences, or to be with their families. The above discussed issues are a few examples of the many factors that induced public TVET and educators in general to be dissatisfied with their rewards and this may have resulted in reduced job satisfaction and morale (Department of Basic Education, 2005, pp.79-81; Adedeji \& Olaniyani, 2011, p. 7).

\section{FACTORS INFLUENCING PUBLIC TVET EDUCATORS MORALE}

From above discussions it is evident that South African public TVET educators were specifically affected by a barrage of policy changes from 1994 (Papier, 2008, p. 6). First to be undertaken was the rationalization and merging of 152 technical colleges in the year 2000. The result of the rationalisation process was the establishment of 50 public TVET institutions under the management of college councils. However, educators' frustrations came in the form of uncertainty of who was their real employer, the DHET or college councils. Educators also lacked teaching resources and faced unruly learners who could even attack them. Educators were also over-worked as they were expected to manage oversized classes and felt poorly remunerated (Davids, 2010).

The Further Education and Training (FET) Colleges Act (RSA 2000) transferred the responsibility for the recruitment and selection of public TVET educators to college councils, but this responsibility has since reverted back to the DHET since 2012 (McBride et al., 2009, p. 22). In addition, earlier research revealed that before the year 2006, public TVET educators were employed by the state (McBride et al., 2009). During this period, public TVET educators were employed in what was termed 'non-establishment' positions. This meant that these positions were college appointments and educators were not happy about this arrangement as they felt that the benefits and rewards they received were not at par with what colleagues who were directly under the employment of the DHET received (McBride et al., 2009).

The major recapitalization of public TVET colleges much needed infrastructure refurbishment was implemented in 2006. This was done through extensive curricular reforms and the phasing out of college outdated curricula. The outdated curriculum better known as the National Education Diploma (NATED) curricula was replaced by the National Vocational Certificate (NCV) in 2007. However, it should be noted that public TVET institutions have since reverted to the outdated NATED curricula. Due to these several changes, public TVET college educators were given the option of remaining Provincial Department of Education employees subject to redeployment or transfer to college councils in 2007. These public TVET educators were now under the control or authority of college council conditions of employment after an initial 12 months period with effect from October 31, 2007, which they felt was a disadvantage as alluded to earlier on. However, 
public TVET institutions have since reverted to DHET since 2012 and one can imagine how much these changes affected public TVET educators. These transformations were geared towards affording public Technical Vocational Education and Training (TVET) colleges more autonomy and public accountability (McBride et al., 2009, p. 22). However, the changes created more confusion for public TVET educators. The changes were a huge cause of reduced job satisfaction and morale for public TVET educators. The educators did not know what the future held. The colleges themselves and the provincial governments did not yet fully comprehend the import of the new governance issues. These policy changes created new dynamics in staff recruitment and retention in the public TVET sector (Wedekind, 2010, p. 6).

Public TVET educators and the generality of educators were affected by the conditions of work in the South African education sector. When educators are not satisfied with their working conditions they seek better teaching conditions elsewhere. Educators' levels of job satisfaction are directly influenced by the South African teaching and learning conditions. However, it should be noted that educators' attrition from the education sector is not only confined to South Africa. Other neighboring African countries TVET sectors are also affected by educator attrition (Department of Basic Education, 2005, pp. 79-81). For example, the attrition rate of educators in Botswana in 2001 was $14 \%$, and in Swaziland it was $12 \%$. In the United Kingdom, the attrition rate of educators was $15 \%$ in 2000. These statistics indicate that educators' job satisfaction in these countries was poor. Effects of poor teaching and learning conditions have generally been overlooked to a large extent in African countries. The implications of overlooking the effects of poor teaching and learning conditions in the education sector are enormous in South Africa. For example, school security and violence in urban schools and TVET colleges especially in high density suburbs is open to conditions prone to violence, poverty, prostitution, drugs abuse and delinquency. The abovementioned factors have also influenced the job satisfaction and morale of educators in general, including public TVET educators. Educators themselves have not been spared of the abovementioned effects of poor learning conditions (ELRC, 2005, p. 36).
In addition to the above difficult conditions under which educators operate, educators' workload was a possible cause of educators' high attrition rate. Educators are perceived to have favorable working hours, as well as the benefits of long college holidays by those who do not fully understand the vagaries of the teaching profession. However, letters from educators in newspapers have shown that in addition to tutoring, educators were expected to be available after hours and over weekends for extra-curricular activities such as sports, parents' evenings, college activities and training sessions. Educators in general, including public TVET educators, also spent long hours at home crafting lesson plans, marking and labouring through administrative work related to their work. Administrative work that educators must fulfil at home related to marking, setting of tests and examinations among others. This leaves educators with little time to spend with their families (Department of Basic Education, 2005, p. 80; Soudien, 2010, p. 58).

Although the ELRC Collective Agreement 1 of 2013 stipulated the normal workload of educators, increased educator workload in public TVET institutions partly resulted from increased administrative tasks due to different curricula introduced since 1996. In addition, the location of learning institutions, whether rural, urban, or semi-urban influenced the nature of educator responsibilities. Because of this, educators' responsibilities differed considerably. There were also historical challenges institutions faced, as well as challenges that related to the location of the institution that had to be dealt with by individual institutions. In addition, the time public TVET educators spent at educational institutions during the day also depended on historical differences of schools. What occupied educators' time most was also influenced by the historical aspects. For example, some urban public TVET institutions have always insisted that educators go the extra mile in working extra hours for the good of the learners. Public TVET college sizes and class size in terms of overcrowding, shortages of learning materials and resources and increased administrative tasks for staff was another problem reduced the job satisfaction and morale of educators. Gender based differences and bias focusing on what educators do were still prevalent in some institutions. For example, female educators are still discriminated against in terms of 
promotional opportunities and decision-making involvement. This discrimination and gender bias relates to lack of promotional opportunities for females as principals and heads of departments (Department of Basic Education, 2005, p. 80).

Different cohorts of learners also spent different amounts of time on specific activities. This is sometimes caused by the nature of the learning disciplines offered. As a result, educators find it difficult to meet demands of Outcomes Based Education and Training (OBET). The abovementioned problems were compounded by an acute shortage of teaching and learning resources, and the effect of the requirements of the implementation of the Integrated Quality Management System (IQMS) (Adedeji \& Olaniyani, 2011, p. 7; Department of Basic Education, 2005, p. 81).

IQMS is perceived as an effort by management to encourage educators to plan and chart their own career development in collaboration with their peers and other stakeholders. IQMS is a tool and process designed to provide a reliable instrument to assist in the evaluation of educators for developmental purposes. The essence of the IQMS system is that anything to do with employee career development is the sole responsibility of each individual employee. The employer only offers support in enabling employees to make sound choices, as well as financial support. However, there were differences in interpretation of the criteria applied when implementing the IQMS. It has been observed that the implementation of IQMS has been ineffective. Many problems and inconsistencies have been highlighted in the implementation of the system. There have been many complaints indicating that the system has been afforded insufficient time to test it and organizational lack of development and support. The IQMS is also viewed as time consuming and with too much bureaucratic controls or bottlenecks (Department Higher Education and Training, 2013, pp. 98-99; Moghli \& Azizi, 2011).

\section{METHODOLOGY}

This study utilized a quantitative research design approach. The quantitative research design approach assured the validity of the sample size $(n=265)$. The research investigated the influence of TVET educator dissatisfaction with extrinsic and intrinsic rewards on the job satisfaction and resultant morale of educators. A stratified purposive sample size of $n=265$ participants was utilized for this study. The survey design was utilised (Polonsky \& Waller, 2011). It is worth noting that in Human Resource Management (HRM) research, researchers rarely use the quantitative research design approach. It was hoped that, if successful, utilization of the quantitative approach in HRM could immensely contribute to sound empirical research/applied research. An independent variable (Extrinsic or intrinsic reward) was presumed the cause of the dependent variable (Job satisfaction and morale), or the presumed effect as described in the schematic diagram of the theoretical framework, depicted in Figure 1 (Zikmund et al., 2013, pp. 118-119; Cooper \& Schindler, 2014, pp. 55-57).

Source: Adapted from Sekaran and Bougie (2016, p. 72).

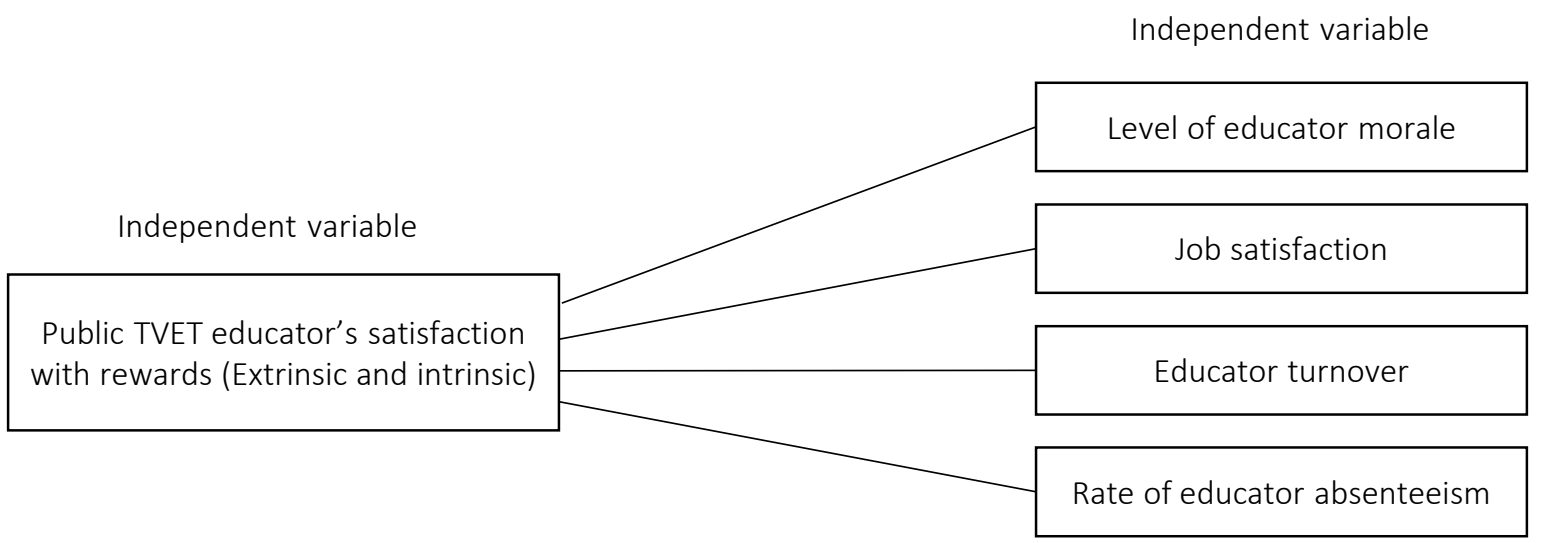

Figure 1. Schematic diagram of the theoretical framework 
The Job Descriptive Index (JDI) which is the most popular and utilized method for measuring job satisfaction of employees in any organisation was utilised in this paper (Arshad, 2014, p. 94; Azeem, 2010 , p. 296). The JDI has scales that provide a faceted approach to the measurement of job satisfaction in terms of specific identifiable characteristics of a job. It measures five aspects of an employee's job satisfaction. For example, it measures an employee's satisfaction with pay, promotion opportunities, supervision and co-workers, and with the job itself (Arshad, 2014, p. 94; Balzer, Brodke, J. Gillespie, \& M. Gillespie, 2017).

\section{RESULTS AND DISCUSSION}

\subsection{Dimensions of job satisfaction}

The dimensions of the job satisfaction of public TVET educators are discussed under this section. Information discussed is deciphered from tables generated through the utilization of SPSS version 23 processed data.

Table 1. Descriptive statistics for dimensions of job satisfaction

\begin{tabular}{l|c:c:c:c:c}
\hline \multicolumn{1}{c}{ Variable } & $N$ & Min & Max & Mean & $\begin{array}{c}\text { Std. } \\
\text { deviation }\end{array}$ \\
\hline $\begin{array}{l}\text { Extrinsic reward } \\
\text { satisfaction (scale) }\end{array}$ & 265 & 1.00 & 3.00 & 2.4080 & 0.65699 \\
\hline $\begin{array}{l}\text { Intrinsic reward } \\
\text { satisfaction (scale) }\end{array}$ & 265 & 1.00 & 3.00 & 2.6673 & 0.55499 \\
\hline $\begin{array}{l}\text { Level of staff morale } \\
\text { (scale) }\end{array}$ & 265 & 1.00 & 2.88 & 1.4675 & 0.41020 \\
\hline $\begin{array}{l}\text { Job satisfaction (scale) } \\
\text { of }\end{array}$ & 265 & 1.07 & 2.81 & 1.9487 & 0.31827 \\
\hline
\end{tabular}

In Table 1 , it was illustrated that, with mean values for different dimensions of job satisfaction of $2.4080,2.6673,1.4675$ and 1.9487, respectively, and a mean of 3.00 as an acceptable cut-off, an accept- able average level of job satisfaction was represented in all the mean ranges displayed in Table 1 . This meant that extrinsic and intrinsic rewards could be utilized to explain the job satisfaction and morale of public TVET educators.

In Table 2, as compared to other levels of education such as the Diploma, Degree, Master's degree and Other qualifications, the Master's degree t-test results of 11.168 was the only one which was positive among other educational qualifications held by public TVET educators (see Table 2). This illustrated that holders of Master's degree among public TVET educators had high job satisfaction and morale.

Table 3. Extrinsic reward satisfaction scale

\begin{tabular}{l|c|c|c|c}
\hline \multicolumn{1}{c}{ Source } & $\boldsymbol{F}$ & df1 & df2 & Sig. \\
\hline Corrected model & 23.559 & 12 & 244 & 0.000 \\
\hline $\begin{array}{l}\text { Staff Morale_Scale } \\
\text { IntrRewSatis_Scale }\end{array}$ & 1.984 & 1 & 244 & $0.160^{* *}$ \\
\hline JobSatis_Scale & 1.160 & 1 & 244 & 0.283 \\
\hline Age & 30.983 & 1 & 244 & $0.000^{* *}$ \\
\hline Tenure & 4.133 & 1 & 244 & $0.043^{*}$ \\
\hline $\begin{array}{l}\text { Gender } \\
\text { Number of years in }\end{array}$ & 0.029 & 1 & 244 & 0.864 \\
position & 0.051 & 1 & 244 & 0.821 \\
\hline $\begin{array}{l}\text { Post level } \\
\text { Level of education }\end{array}$ & 0.181 & 1 & 244 & 0.671 \\
\hline
\end{tabular}

Note: Figures with asterisks $*$ and ${ }^{* *}$ in Table 2 denote the probability values at 5 per cent and 10 per cent levels of significance, respectively.

In Table 3, it was illustrated that age was negatively influenced by extrinsic rewards at 5 per cent level of significance. This could be the reason why the majority of young educators as compared to older educators left the teaching profession to seek employment opportunities elsewhere perceived to be more attractive in terms of conditions of work (European Commission, 2013).

Table 2. Deviation contrast

\begin{tabular}{|c|c|c|c|c|c|c|c|}
\hline \multirow{2}{*}{$\begin{array}{l}\text { Level of education deviation } \\
\text { contrasts }\end{array}$} & \multirow{2}{*}{$\begin{array}{l}\text { Contrast } \\
\text { estimate }\end{array}$} & \multirow{2}{*}{$\begin{array}{l}\text { Std. } \\
\text { error }\end{array}$} & \multirow[t]{2}{*}{$\mathbf{T}$} & \multirow[t]{2}{*}{ Df } & \multirow[t]{2}{*}{ Adj. Sig. } & \multicolumn{2}{|c|}{$\begin{array}{l}\text { 95\% confidence } \\
\text { interval }\end{array}$} \\
\hline & & & & & & Lower & Upper \\
\hline Diploma-mean & -0.157 & 0.028 & -5.649 & 243 & $0.000 * *$ & -0.211 & -0.102 \\
\hline Degree - mean & -0.138 & 0.025 & -5.563 & 243 & $0.000 * *$ & -0.187 & -0.089 \\
\hline Master's degree - mean & 0.412 & 0.037 & 11.168 & 243 & $0.000 * *$ & 0.340 & 0.485 \\
\hline Other-mean & -0.118 & 0.031 & -3.788 & 243 & $0.000 * *$ & -0.179 & -0.056 \\
\hline
\end{tabular}

Note: Figures with asterisks * and ** in Table 2 denote the probability values at 5 per cent and 10 per cent levels of significance, respectively. 
Table 4. The Pearson correlation matrix for dimensions of job satisfaction

\begin{tabular}{l|c}
\hline \multicolumn{1}{c|}{ Dimension } & Job satisfaction \\
\hline Work in present job & $1.000^{* *}$ \\
& $(0.000)$ \\
\hline Present pay & $-0.43922^{*}$ \\
Present opportunities for & $(0.01617)$ \\
promotion & $-0.48992^{* *}$ \\
Supervision & $(0.00753)$ \\
& 0.30517 \\
Co-workers & $(0.288708)$ \\
\hline
\end{tabular}

Note: Figures with asterisks * and ** denote the probability values at 5 per cent and 10 per cent levels of significance, respectively.

The results in Table 4 showed that a significant relationship existed between dissatisfaction of educators with intrinsic and extrinsic rewards and educators' low job satisfaction and low morale. The values of present pay (extrinsic reward) and present opportunities for promotion (intrinsic reward) were negative (see Table 4) There was an inverse relationship between job satisfaction and present opportunities for promotion (-0.48992), and an inverse relationship between job satisfaction and present pay (-0.43922) as well.

Table 5. Pearson's product moment correlation

\begin{tabular}{l|c:c:c:c}
\hline \multicolumn{1}{|c}{ Source/dimensions } & $\boldsymbol{F}$ & $\mathbf{d f 1}$ & $\mathbf{d f 2}$ & Sig. \\
\hline Corrected model & 214.747 & 13 & 243 & 0.000 \\
Staff morale scale & 18.718 & 1 & 243 & $(0.000)^{* *}$ \\
\hline $\begin{array}{l}\text { Intrinsic reward } \\
\text { satisfaction scale }\end{array}$ & 2.969 & 1 & 243 & $(0.086)^{* *}$ \\
\hdashline Extrinsic reward & 1.353 & 1 & 243 & 0.246 \\
satisfaction scale & & & & \\
\hdashline Age & 0.105 & 1 & 243 & 0.746 \\
Tenure & 0.217 & 1 & 243 & 0.641 \\
Gender & 1.259 & 1 & 243 & 0.263 \\
Number of years & 0.003 & 1 & 243 & 0.957 \\
Post level & 1.019 & 2 & 243 & 0.363 \\
Level of education & 45.015 & 3 & 243 & $(0.000)^{* *}$ \\
\hline
\end{tabular}

Note: Figures with asterisks $*$ and $* *$ denote the probability values at 5 per cent and 10 per cent levels of significance, respectively.

In Table 5, it was revealed that no relationship existed between dissatisfaction of educators with intrinsic and extrinsic rewards with the low job satisfaction experienced by educators. A significant relationship however existed between dissatisfaction of educators with extrinsic and intrinsic rewards, and low job satisfaction at 0.1 level of significance (see Table 5).

\subsection{Correlations of independent variables and job satisfaction}

Table 6. Inferential statistics for correlations of independent variable and job satisfaction

\begin{tabular}{l|c:c|c|c}
\hline \multicolumn{1}{c|}{ Source } & $\boldsymbol{F}$ & df1 & df2 & Sig. \\
\hline Corrected model & 23.559 & 12 & 244 & 0.000 \\
\hline Staff morale scale & 1.984 & 1 & 244 & 0.160 \\
\hline $\begin{array}{l}\text { Intrinsic reward } \\
\text { satisfaction scale }\end{array}$ & 1.160 & 1 & 244 & 0.283 \\
\hline Job satisfaction scale & 30.983 & 1 & 244 & $0.000^{* *}$ \\
\hline Age & 4.133 & 1 & 244 & $0.043^{*}$ \\
\hline Ten & .029 & 1 & 244 & 0.864 \\
\hline Gender & .051 & 1 & 244 & 0.821 \\
\hline Number of years & .181 & 1 & 244 & 0.671 \\
\hline Post level & .160 & 2 & 244 & 0.852 \\
\hline Level of education & 45.015 & 3 & 243 & $0.000^{* *}$ \\
\hline
\end{tabular}

Note: Figures with asterisks $*$ and $* *$ denote the probability values at 5 per cent and 10 per cent levels of significance respectively.

Table 6 illustrated the existence of a statistically significant relationship between job satisfaction, and intrinsic and extrinsic rewards at 0.1 level of significance. At 0.05 level of significance, a significant relationship existed between intrinsic and extrinsic rewards and the age of respondents.

In Table 6, the findings also revealed that a significant relationship existed between levels of education public TVET educators held and job satisfaction at 0.05 level of significance (see Table 6).

As illustrated in Table 1, with mean values for different dimensions of job satisfaction of 2.4080, $2.6673,1.4675$ and 1.9487 , respectively, and with a mean of 3.00 representing an acceptable average level of job satisfaction, the findings indicated that public TVET educators were more satisfied with intrinsic rewards as compared to extrinsic rewards. As implied by the findings, it was confirmed that money was not the ultimate element of satisfaction that public TVET educators looked for in their jobs although it is an important motivator. There were other elements of satisfaction that public TVET educators looked for such as collegiality, styles of supervision and the job itself to mention a few examples (Tredoux \& Durrheim, 2013, p. 61; Cao et al., 2013, p. 63).

In Table 2, it was shown that as compared to other levels of education such as the Diploma, Degree, 
Master's degree and Other qualifications, the Master's degree t-test results of 11.168 , which was the only one which was positive among other educational qualifications held by public TVET educators, showed that educators with higher qualifications were more stratified with intrinsic rewards (see Table 2). This finding implied that the Master's degree holders were more satisfied with their jobs than holders of other educational qualifications. The above finding could have implied that public TVET educators who held higher qualifications such as the Master's degree derived their job satisfaction and resultant high morale from intrinsic rewards that accompanied their jobs. It is possible that Master's degree holders were afforded opportunities of enjoying intrinsic rewards such as long holidays, autonomy and accountability in how they performed their tasks in the public TVET sector. It is argued that under the abovementioned conditions, work becomes more interesting since educators do not experience monotony (Nujjor \& Meyer, 2012). The above findings also confirm the claim that money is not the ultimate reward that educators look for in their jobs. Educators are looking for other types of motivators as mentioned previously (Keegan \& Green, 2014, pp. 84-85; Raj, 2008-2010; Bussin, 2014; Shields, 2007, p. 31). To support this claim, in Greece, it was discovered that educators were satisfied by the job itself and how they were supervised, and the autonomy they experienced in carrying-out their tasks (Gkolia et al., 2014, p. 327).

In this paper, it was also discovered that the higher the age of public TVET educators, the lower satisfaction with extrinsic rewards educators had. In South Africa, young educators, just like in European countries are inducted or socialized when they join the teaching profession, but youths are not eager to join the teaching profession because of perceived poor remuneration. This disposition of young educators was ascribed to the argument that young educators felt that since they were still young and strong, they could adventure into other jobs which appeared more attractive than teaching. Because of these reasons, it was argued that educational institutions in general would lose more young people than old educators as long as young people perceived salaries offered in the education sector poor as compared to other attractive jobs outside the teaching profession (Van Zyl, 2010, p. 2).
This study also discovered that morale of public TVET educators was influenced by extrinsic rewards (see Table 3). A statistically significant relationship existed between job satisfaction and extrinsic rewards at 10 per cent significance level. This implied that job satisfaction of public TVET educators was positively influenced by extrinsic rewards. The above is confirmed by the fact that salaries and working conditions in public TVET institutions were found to be decisive elements in the choice of a career choices in Finland and Ireland. The majority of educators looked for good pay in their careers. This indicated, as previously discussed that extrinsic rewards cannot be discounted as sources of employee job satisfaction and resultant morale for public TVET educators. Educators look for money in their jobs to meet their basic needs such as shelter and food. It can be deciphered from the above insinuation, that educators look for both extrinsic and intrinsic rewards at the same time but prioritize which of the two is the most important at different phases of their working life. And this is what the employer should identify and isolate in order to come up with a rewards combination that most appeals to employees (Aguinis, 2013, p. 13).

In Finland, the teaching profession has always been held in high regard. There is no shortage of educators because of a variety of incentives offered in Finland's and Ireland's TVET sector. Salary levels for educators in these two countries are supplemented by incentives and good working conditions. Again, this attests to the plausibility of the argument that employees may be looking for both intrinsic and extrinsic rewards (total rewards) in different combinations in their work (Hutchinson et al., 2014, p. 10).

Table 3 also illustrated that age of public TVET educators was negatively influenced by extrinsic rewards at 5 per cent level of significance. This finding may have meant that the older the educator, the lower extrinsic reward satisfaction. This could have further meant that older educators could be looking for more intrinsic rewards as compared to extrinsic rewards in their work. However, the statistics in Table 3 pointed to the fact that extrinsic rewards play a big role in enhancing the job satisfaction and morale of public TVET educators of different ages in different ways and cannot be 
discounted as a contending motivator for different ages of public of TVET educators, because they look for different rewards (Tucker, 2012, p. 8).

The results in Table 4 illustrated that a significant relationship existed between dissatisfaction of educators with intrinsic and extrinsic rewards and educators' reduced job satisfaction and morale. The values of present pay (extrinsic reward) and present opportunities for promotion (intrinsic reward) were negative. There was an inverse relationship between job satisfaction and present opportunities for promotion (-0.48992), and an inverse relationship between job satisfaction and present pay $(-0.43922)$ as well.

The negative inverse relationship between job satisfaction and present opportunities for promotion could have been brought about by the fact that female educators in the Public TVET institutions were still discriminated against in terms of promotional opportunities. Although women were in the majority, they were not being afforded opportunities for promotion as principals or Heads of Departments (Adedeji \& Olaniyani, 2011, p. 7; Department of Basic Education, 2005, p. 81).

It was also discovered that there was a negative significant relationship between present pay $(-0.43992)$ and public TVET educators' job satisfaction at 0.1 level of significance. This could be explained by the fact that some educators were frustrated by the fact that they were not reaching their top-level salary grades at a relatively early and younger age in their careers. Educators found themselves with no prospects of a better income and were frustrated (European Commission, 2013, p. 63). Therefore, no relationship existed between educators' dissatisfaction with intrinsic and extrinsic rewards and educators' reduced morale.

The results however showed that there was a significance relationship between job satisfaction and work in present job with a $p$ value of 0.00 at 0.10 level of significance. This might have been explained by the fact that there were public TVET educators, for example those who held Master's level of education who seemed to derive job satisfaction from the fact that they were afforded some latitude to plan how to manage their tasks among other reasons (Zhoutao et al., 2013).
Using the results in Table 5, a significant relationship however existed between dissatisfaction of educators with intrinsic and extrinsic rewards, and low job satisfaction at 0.1 level of significance. The findings in Table 5 were supported by the fact that both intrinsic and extrinsic rewards influenced the job satisfaction and resultant morale of public TVET educators. Non-cash rewards, welfare, work-life balance, appreciation, recognition and development opportunities, as well as scope to exercise responsibility, influence job satisfaction and morale of public TVET educators. This finding confirms and recommends that it would be wise for public TVET to introduce Total rewards as they often cater for the different needs of educators as previously suggested (Shields, 2007, p. 31; Zhoutao et al., 2013, p. 63).

Interpretations from Table 4 indicated that there was an inverse relationship between job satisfaction and present opportunities for promotion (non-monetary rewards). A relationship existed between the independent variable (intrinsic and extrinsic rewards) and job satisfaction (dependent variable) although it was weak. A statistically significant relationship existed between present pay and job satisfaction at the 0.05 level of significance with a $p$ value of -0.43922 implying that present pay and job satisfaction have a weak or inverse relationship. This was the case because the $p$ value was $<0.2$. A statistically significant relationship was also found between present opportunities for promotion and job satisfaction of employees at the 0.1 level of significance with a $p$ value of -0.48992 . This $\mathrm{p}$ value was $<0.2$ which implied that there was an inverse relationship between the two variables being compared with each other to ascertain the strength of their relationship which was negative (see Table 4).

\subsection{Correlations of independent variables and job satisfaction}

Table 6 showed existence of a statistically significant relationship between job satisfaction, and intrinsic and extrinsic rewards at 0.1 level of significance. At 0.05 level of significance, a significant relationship existed between intrinsic and extrinsic rewards and the age of respondents. Youths are reluctant to join the teaching profession because they consider it unattractive. Young educators 
leave the teaching profession for more attractive job opportunities elsewhere. This confirms that different age groups look for different rewards in the teaching profession. The DHET could take a cue and come up with a reward system (total rewards) that could appeal to different ages in this sector as previously suggested (Van Zyl, 2010, p. 2).

The findings in Table 6 also revealed that a significant relationship existed between levels of edu- cation public TVET educators held and their job satisfaction at 0.05 level of significance. This finding is corroborated by the European Commission (2013), which discovered that diverse rewards such as degree of autonomy, involvement in tailoring reforms and being given autonomy to be innovative contributed to job satisfaction of public TVET educators. This also contributed to a favorable image of the teaching profession in the society (European Commission, 2013, p. 7).

\section{CONCLUSION}

The overall conclusion reached was that both extrinsic and intrinsic rewards significantly predicted the job satisfaction and morale of Public TVET educators in public TVET institutions in the Western Cape. Total rewards (extrinsic and intrinsic) were recommended as the best form of rewards model that could enhance the job satisfaction and morale of public TVET educators of different ages and gender. Public TVET educators job satisfaction and morale could be improved by the job itself, especially how it is designed. The type of supervision, and public TVET institution's working environment and atmosphere, as well as granting educators the autonomy to make teaching decisions was also important in enhancing the job satisfaction and resultant morale of public TVET educators. Provision of promotional and growth opportunities especially to female educators who are still discriminated against in this regard, and provision of teaching resources and reduced workloads were discovered to be part of the Total reward package that could be used to enhance educators' job satisfaction and morale.

Educators in Western Cape public TVET institutions were found to be more satisfied with intrinsic rewards as compared to extrinsic rewards. However, the findings also confirmed that money was important in influencing the job satisfaction and the resultant morale of public TVET educators was not the ultimate goals in all employees in their work. The study revealed that money could also act as a general reinforcing agent as it was associated with valued rewards. However, the argument behind this idea was that money is a reward on its own right. Hence the suggestion that public TVET institutions in the Western Cape adopt the Total Rewards Model, which would cater for the different needs of different educators (Bussin, 2014).

To make the task of rewarding different categories of Public TVET educators easier and manageable, the study helped reveal and identify their preferences. For example, educators who held the Master's degree qualification, the old-aged and female educators were found to derive increased job satisfaction and morale from intrinsic rewards while young educators preferred extrinsic rewards, especially quick ascendance to top salary levels within a few years of joining teaching. Failure of which would make them seek greener pastures elsewhere (European Commission, 2013; Van Zyl, 2010). These findings could enable public TVET institutions or the DHET to realize which type of rewards to emphasize in a reward package when rewarding different categories of educators.

However, from the findings and discussions carried out, it was concluded that extrinsic and intrinsic rewards were both important for particular reasons and for satisfying the different needs of different categories of public TVET educators in meeting their needs. It was acknowledged that rewards packages may need to be in different proportions (tailor-made) in a reward package (extrinsic and intrinsic reward proportions) depending on the needs of individual employees at different times. This requirement would call for careful studies to be conducted in order for an organization to be effective in reward man- 
agement. In essence, that is why it was suggested that public TVET institutions in the Western Cape adopt the Total Rewards Model as a solution to the challenges the sector has been facing in rewarding educators.

\section{ACKNOWLEDGEMENTS}

Great indebtedness is felt towards the Western Cape Provincial Department of Education for granting permission for this study carried out in the five Public TVET colleges in Cape Town. These are Public TVET colleges such TVET College of Cape Town, Boland TVET College, False Bay TVET College, Northlink TVET College and West Cost TVET Colleges. Many thanks also go to the Principals and academic staffs of these colleges who agreed to participate in the study and cooperated throughout the whole process.

\section{REFERENCES}

1. Adedeji, S. O., \& Olaniyani, O. (2011). Improving the conditions of teachers and teaching in rural schools across African countries. Addis Ababa: UNESCOInternational Institute for Capacity Building. Retrieved from https:// unesdoc.unesco.org/ark:/48223/ pf0000216062

2. Aguinis, H. (2013). Performance management (3rd ed.). New York: Pearson.

3. Arshad, Z. (2014). Impact of JDI and personality traits on job satisfaction. IOSR Journal of Business Management, 16(1), 91-97. http:// dx.doi.org/10.9790/487X-16119197

4. Azeem, S. M. (2010). Job satisfaction among employees in Sultanate of Oman. Psychology, 1(4), 295299. https://doi.org/10.4236/ psych.2010.14038

5. Balzer, W. K., Brodke, M. R. N., Gillespie, J. Z., \& Gillespie, M. A. (2017). The Job Descriptive Index (JDI). Ohio: Bowling Green State University.

6. Bennell, P., \& Akyeampong, A. (2007). Teacher motivation in Sub-Saharan Africa and South Asia. London: Department of International Development. Retrieved from https://www.gov. uk/dfid-research-outputs/teachermotivation-in-sub-saharan-africaand-south-asia-researching-theissues-71
7. Bussin, M. (2014). Remuneration and talent management: Strategic compensation approaches for attracting, retaining and engaging talent. Johannesburg: Knowres Publishing (Pty), Ltd. Retrieved from https://www.amazon.com/ Remuneration-Talent-Management-compensation-approachesebook/dp/B00Q4SFC8W

8. Buthelezi, Z. (2018). Lecturer experiences of TVET College challenges in the post-apartheid era: a case of unintended consequences of educational reform in South Africa. Journal of Vocational Education and Training, 70(3), 364383. Retrieved from https://www. tandfonline.com/doi/full/10.1080/1 3636820.2018 .1437062

9. Cao, Z., Chen, J., \& Song, Y. (2013). Do total rewards reduce the core employees' turnover intentions? International Journal of Business Management, 8(20), 62-75. https:// doi.org/10.5539/ijbm.v8n20p62

10. Chanza, A. W. D., Snelgar, R. J., Song, Y., \& Louw, G. J. (2013). The motivational value of rewards amongst Malawi's health professionals. South African Journal of Human Resource Management, 11(1), 517. Retrieved from https:// sajhrm.co.za/index.php/sajhrm/ article/view/517/666

11. Cooper, D. R., \& Schindler, P. S. (2014). Business research methods (12th ed.). New York: McGraw-Hill Education.
12. Davids, B. (2010). Teaching is not an essential service. The New Negotiator, 3(3), 1-9.

13. Education Labour Relations Council (ELRC). (2013). Collective Agreement 1 of 2013: Generic Contract of Employment. Pretoria: ELRC - FETC Bargaining Unit.

14. ELRC. (2005). Educator supply and demand in the South African Public Education System. Integrated report. Cape Town. HSRC Press.

15. ETPD SETA. (2009/2010). Sector skills plan for the period 2005-2010: Update 2009/2010. Johannesburg: ETPD SETA.

16. European Commission. (2013). Study on policy measures to improve the attractiveness of the teaching profession in Europe. Copenhagen: European Commission.

17. FET Round Table. (2010). Challenges facing the Technical Vocational Education Training (TVET) College Sub-system: Towards finding resolutions in partnership with stakeholders. Pretoria. The Technical Vocational Education Training (TVET) Round Table.

18. FETI. (2009). National symposium on development for vocational and occupational trainers and educators. Cape Town: FETI.

19. Foot, M., \& Hook, C. (1999). Introducing Human Resource Management (2nd ed.). England: Pearson Education Limited. Retrieved from https://www. 
amazon.co.uk/Introducing-HumanResource-Management-Margaret/ dp/0273740989

20. Gkolia, A., Belias, D., \& Koustelios, A. (2014). Teachers' job satisfaction and self-efficacy: A review. European Scientific Journal, 10(22), 321-342. Retrieved from https:// eujournal.org/index.php/esj/article/ view/3923

21. Hussain, I. A., Yunus, N. A., \& Daud, N. (2013). The influence of intention to leave towards employee engagement among young bankers in Malaysia. International Journal of Business and Management, 8(14). https://doi.org/10.5539/ijbm. v8n14p89

22. Hutchinson, J., Neary, S., Marriot, J., \& Jackson, H. (2014). Strategic consultation on FE workforce and initial teacher education for the Education and Training Foundation. Derby: University of Derby. Retrieved from https:// derby.openrepository.com/handle/10545/324064

23. Jeremiah, A. (2018). The effect of employee rewards on staff morale in Western Cape Public TVET colleges (Unpublished Ph.D. Thesis). Cape Peninsula University of Technology, Cape Town.

24. Keegan, W. J., \& Green, M. C. (2015). Global marketing (8th ed.). Essex: Pearson.

25. Lake, C. J., Gopalkarishnan, Sliter, M. J., \& Withrow, S. (2010). The Job Descriptive Index: Newly Updated and Available for download. Ohio: Bowling Green State University.

26. McBride, T., Papier, J., \& Needham, S. (2009). Technical Vocational Education Training (TVET) College Lecturers in the Western Cape. University of the Western Agricultural Cape. Further Education and Training Institute (Technical Vocational Education Training (TVETI).

27. Meyer, M., \& Kruger-Pretorius, E. (2018). Introduction to Human Resource Management. Pretoria: Van Schaik.

28. Moghli, A., \& Azizi, A. (2011). Manpower productivity management. Tehran. Payane Noor University.
29. Nel, P. S., Hasbroek, G. D., \& Werner, A. (2008). Human Resources Management (7th ed.). Sothern Africa: Oxford University Press.

30. Ngambi, H. C. (2011). The relationship between leadership and employee morale in higher education. African Journal of Business Management, 5(3), 762776. Retrieved from https://www. semanticscholar.org/paper/The-relationship-between-leadership-andemployee-in-Ngambi/917c8c898f3b 8ef244802b6f20c6018cc728cfa0

31. Nujjo, A., \& Meyer, I. (2012). The relative importance of different types of rewards for employee motivation and commitment in South Africa. South African Journal of Human Resource Management, 10(2), 1-10. https://doi.org/10.4102/ sajhrm.v10i2.442

32. Papier, J. (2008). Report on training of Technical Vocational Education Training (TVET) lecturers in South Africa, England and other contexts. Wynberg: Technical Vocational Education Training (TVET). University of Western Cape.

33. Polonsky, M. J., \& Waller, D. S. (2011). Designing and managing a research project: A business student's guide. London: Sage Publications Ltd.

34. Quinlan, Babin, Carr, Griffin, \& Zikmund (2015). Business Research Methods (1st ed.). U.K.: CENGAGE Learning.

35. Raj, P. (2008-2010). The benefits of a total rewards approach: A look at World at Work Total Rewards Model.

36. Sekaran, U., \& Bougie, R. (2016) Research methods for business. A skill-building approach (7th ed.). United Kingdom: John Wiley \& Sons.

37. Shields, J. (2007). Managing employee performance and rewards. London: Cambridge University Press.

38. Soudien, C. (2010). Transformation in higher education: A briefing paper. Pretoria. Development Bank of Southern Africa.

39. The Department of Basic and Higher Education and Training
(2011). Integrated strategic planning framework for teacher education and development in South Africa. South Africa. Pretoria.

40. The Department of Basic Education (2006). Further Education and Training Act (Act No. 16 of 2006). South Africa. Pretoria. Government Printer.

41. The Department of Basic Education (2009). Trends in education macro indicators report. South Africa. Pretoria.

42. The Department of Basic Education. (2005). Teachers for the future. Meeting teacher shortages to achieve education for all. South Africa. Pretoria.

43. Tredoux, C., \& Durrheim, K. (2013). Numbers, hypotheses \& conclusions: A course in Statistics for the Social Sciences (2nd ed.). Cape Town: UCT Press.

44. Tucker, M. S. (2012). The phoenix: Vocational education and training. Singapore: Centre of International Education Bench Marking.

45. Van Zyl, G. (2010). Does employee remuneration dispensation in the South African economy enhance labour production? The Gauteng Manufacturing Industry as a case study. South African Journal of Human Resource Management, 8(1), 286-291. Retrieved from https:// sajhrm.co.za/index.php/sajhrm/ article/view/286/275

46. Wedekind, V. (2010). Chaos or coherence? Further education and training college governance in postapartheid South Africa. South Africa. University of Kwazulu Natal.

47. Zhoutao, O., Jinxi, C., \& Yixiao, S. (2013). Does total rewards reduce employees' turn-over? International Journal of Business and Management, $8(20), 62-75$. Retrieved from https:// pdfs.semanticscholar.org/57d3/3e d81ff3c80b5ca030556a7ac9fd8cf19 elb.pdf

48. Zikmund, W. G., Banin, B. J., Carr, J. C., \& Griffin, M. (2013). Business research methods (9th ed.). United Kingdom: South-Western Cengage Learning. 